\title{
Potential of stingless bee farm for agriculturally based urban community development in Bandung, West Java
}

\author{
Dika Supyandi ${ }^{1,2,3^{*}}$, Parikesit ${ }^{2}$, and Iwan Setiawan ${ }^{3}$ \\ ${ }^{1}$ Postgradudate Student on Environment Science, Universitas Padjadjaran, Indonesia \\ ${ }^{2}$ Center for Environment and Sustainability Science, Universitas Padjadjaran, Indonesia \\ ${ }^{3}$ Faculty of Agriculture, Universitas Padjadjaran, Indonesia
}

\begin{abstract}
The existence of pollinators is highly significant in ensuring sustainability of agriculture produces. Among several pollinators, bees are the most recognized and common in the plant world. In general, two species of bees are identified, namely sting bees and stingless bees. In a middle of the city of Bandung, several stingless beehives have been kept by a community. This paper aims to describe the process of the bee farm, motives behind the farming, participation of community members, and how far this bee farm activities potential to community development. This paper is written based on qualitative research process implementing deep interview, observations, and interview with stakeholders. The results show that stingless bee farm has the potential to improve the processes and outcomes of urban community development, even though hitherto it has not been carried out commercially and profitable; motives of the farm was for environmental protection reasons such as improving the physical environment in the area not for financial/economic reasons; the participation of group members in various group activities can be categorized to be good; two major impacts received by the community are increased social cohesion among community members and improved quality of the physical environment in the area.
\end{abstract}

\section{Introduction}

Encouraging processes promoting sustainability is a necessary condition in our today agricultural development. Agriculture sector must sustain in order to feed the world. Agricultural practices neglecting sustainability principles must be hindered and the ideas are obsolete [1]. In addition, processes having multiple functions will give several benefits to the sector and to environment [2]. We are identifying processes triggering these several benefits with only deliver a single step, which ultimately influences agriculture product quantity and quality as well as agriculture community cohesion and environment conservation.

One of the processes that potentially have these influences is bee farm practices [3]. Bees are the most important pollinators in natural and agricultural ecosystems in the worlds

* Corresponding author: dika.supyandi@unpad.ac.id 
[4]. Furthermore, bees also produce several products such as honey, propolis, bee pollen, beeswax and royal jelly [5]. Bee farm is also believed resulted in increasing of social capitals among the keepers [6]. Moreover, bee farm encourages the community to cultivate plants that functioned as sources of feed for bees; sources of nectars, pollens, and resins. This plant cultivations will directly or indirectly lead to environment conservation.

In general, we identified two genera of bees, namely sting (can be honey bee/apini) and stingless bees (meliponini) [7]. Beekeeping usually perceived as sting beekeeping, and then somewhat neglected the stingless beekeeping. For several reasons, mainly due to low honey productivity of stingless bees, this beekeeping was not as popular as the other. In fact, stingless bees produce much more propolis than sting bees. On the other hand, modern science identified that the number of stingless bee species is much higher than the sting bees [4]. In addition, because of the stingless bee characteristics, this bee is potential to be kept around people living, which will not harm and do not dangerous to people.

Consider the potential of stingless bee farm, a community in the heart of the City of Bandung, Indonesia started to farm stingless beehives around their area. This community formed a farmer group named "Tamalago", the only farmer group in the City of Bandung focusing on stingless bee farm. This is interesting because the area is a dense settlement, with densely populated and tight buildings. For several reasons, people are wondering how bees' feed can be provided, how the surrounding communities living in the area can accept the farming, and how the farmer group manages its internal business to achieve the group objectives. This paper describes brief explanation of the model of the bee farm, from provision of feed to product utilization, motives behind the farm, participation of community members, and the degree of this bee farm activities potential to community development.

\section{Methodology}

The research behind this paper writing implied qualitative research design applying case study technique. The research implemented observations, used deep interview processes to the leader of the farmer group and several members of the farmer group individually. Interview process has finished as data saturation achieved. The research also collected information gathered from several relevant stakeholders, such as local government and Office of Forestry of West Java Province and Office of Food and Agriculture of Bandung City.

\section{Results and discussion}

The Tamalago farmer group lies in Cibangkong Village, Batununggal District, Bandung City, Indonesia. This farmer group locates at the heart of Bandung City. Since 2019, several community members started to farm beehives in their houses and at several locations in the area, which then transformed to become small community gardens. This farmer group was inspired by a community member who has been farming beehives in her house prior to followed by other community members. This community member, who were later elected as the head of the farmer group, was interested in stingless bees because she had experience of the benefits of stingless bee honey consumption when she was sick, which then encouraged her to farm. Due to the uniqueness of the bees and beehives, as well as the yard condition which was lush and convenient has resulted in the interest of other community members to do the same activities as her.

The Tamalago farmer group was officially formed in October 2020 based on a decree of the Office of Food and Agriculture of the City of Bandung, and then followed by a decree 
of the Office of Forestry of the Province of West Java. This formation inspired by a visit of mayor of Bandung City to the community when he launched a city government program called "Lembur Tohaga Lodaya" in August 2020. The mayor impressed with the community activity and then he stated that this type of activities must be spread and disseminated to all districts in Bandung City. Responding to this statement, the community members then initiated to form a farmer group focusing on the stingless bee farm activities.

\subsection{Characteristics of the farmer group members}

The Tamalago farmer group has 22 members, consist of an advisor, a chairman, a secretary, a treasurer, and several sections (law, public relation, HR, business, plant maintenance, plant nursery, bee breeding and hygiene). Paying attention to the composition of this organization, it appears that this farmer group was formed with professional and wellorganized efforts and steps. Furthermore, the characteristics of farmer group members can be seen in Table 1

Table 1. Characteristics of Farmer Group Members

\begin{tabular}{|l|l|l|r|}
\hline Characteristics & \multicolumn{1}{|c|}{ Category } & \multicolumn{1}{|c|}{ Sub-category } & Quantity \\
\hline \multirow{4}{*}{ Age } & $<40$ & & 1 \\
\cline { 2 - 4 } & $40-60$ & & 18 \\
\cline { 2 - 4 } & $>60$ & & 3 \\
\hline \multirow{5}{*}{ Sex } & Male & & 16 \\
\cline { 2 - 4 } & Female & Elementary School & 6 \\
\hline \multirow{5}{*}{ Occupation } & Basic Education & 1 \\
\cline { 2 - 4 } & \multirow{2}{*}{ Middle Education } & Junior High School & 1 \\
\cline { 3 - 4 } & & Senior High School & 6 \\
\cline { 2 - 4 } & & Diploma & 3 \\
\cline { 3 - 4 } & \multirow{3}{*}{ Higher Education } & Bachelor Degree & 7 \\
\cline { 3 - 4 } & & Master Degree & 3 \\
\cline { 2 - 4 } & & Doctoral Degree & 1 \\
\hline & Government employees & Teacher & 2 \\
\cline { 2 - 4 } & Private employees & & 6 \\
\cline { 2 - 4 } & Entrepreneur & & 13 \\
\cline { 2 - 4 } & Retired & & \\
\hline
\end{tabular}

Based on the data in Table 1, it can be seen that most of the members are men who are of productive age. Most members are also highly educated, and most work as entrepreneurs. The interesting thing is that the chairman and the secretary of the farmer group are women. In addition, several members of the group have master's and doctoral degrees. Those with low education are cleaners and laborers who work in the area and join the farmer group.

\subsection{Stingless bee farm practices in the community}

In general, model of bee farm practices in the farmer group, in particular technology used can be brief in the Table 2 . In this context, technology is not only defined as physical technology, but also human, information and organisation elements. 
Table 2. Bee Farm Practices in the Farmer Group

\begin{tabular}{|c|c|c|}
\hline No. & Beekeeping Cultivation System & Technology Used \\
\hline 1. & Species farmed & $\begin{array}{l}\text { Heterotrigona itama } \\
\text { Tetragonula laeviceps } \\
\text { Tetragonula biroi }\end{array}$ \\
\hline 2. & Provision of bees' colony & $\begin{array}{l}\text { First colonies: obtained from another location in West } \\
\text { Java (Banjar) } \\
\text { Next colonies: doing own colony splitting }\end{array}$ \\
\hline 3. & Provision of beehives & $\begin{array}{l}\text { Buy from craftsman } \\
\text { Make their own }\end{array}$ \\
\hline 4. & Provision of feeds & $\begin{array}{l}\text { Planting several plants sources of nectars, pollens and } \\
\text { resins }\end{array}$ \\
\hline 5. & $\begin{array}{l}\text { Examples of types of cultivated } \\
\text { plants }\end{array}$ & $\begin{array}{l}\text { Antigonon leptosus/coral vine, coralina, bellisima } \\
\text { grande } \\
\text { Helianthus annuus/sunflower } \\
\text { Xanthostemon chrysanthus } \\
\text { Epiphyllum anguliger/queen of the night } \\
\text { Averrhoa carambola/star fruit } \\
\text { Mangiferaa indica/mango }\end{array}$ \\
\hline 6. & Pests & $\begin{array}{l}\text { Mesostigmata: Varroidae/"varroa" mite } \\
\text { Gekkonidae/house lizard/gecko } \\
\text { Formicidae/ants }\end{array}$ \\
\hline 6. & Harvest and Postharvest & \\
\hline & a. Harvest & Manual harvest, for own consumption \\
\hline & b. Postharvest & Not doing postharvest activities \\
\hline II. & Beekeeping Farm System & \\
\hline 1 . & Farmer institution & $\begin{array}{l}\text { "Tamalago" farmer group as a place to learn and } \\
\text { work together }\end{array}$ \\
\hline 2. & Information provision & $\begin{array}{l}\text { Knowledge of bee keeping is obtained from group } \\
\text { leaders, agricultural extension workers, forestry } \\
\text { extension workers, and visits to other bee-cultivating } \\
\text { groups }\end{array}$ \\
\hline 3. & Source of capital & $\begin{array}{l}\text { Capital is obtained from personal funds, member } \\
\text { contributions and regular membership fees } \\
\text { So far, no government assistance in the form of } \\
\text { capital has been received by the group }\end{array}$ \\
\hline 4. & Marketing & $\begin{array}{l}\text { There is no marketing activity from "Tamalago" } \\
\text { beekeeping } \\
\text { Marketing the products of other groups through } \\
\text { "Tamalago" }\end{array}$ \\
\hline
\end{tabular}

Stingless bee farm is still new for community in this area. Hence, it can be understood if bee farm activities have not been fully carried out intensively. Apart from being still in efforts to increase knowledge, also because almost all members of the farmer group have a main job outside of bee-cultivating activities. However, in general, communities of today's scale can manage the bees they maintain quite well. They can still obtain colonies to raise, provide adequate feed and harvest the resulting honey.

From information showed in Table 2, we also can see that hitherto the community are still cultivating bees for their own consumption and have not yet reached the commercial efforts of the products they produce, even though several researches show that this type of bee farm is profitable in Indonesia [8]. The informant stated that at least 200 beehives are needed to be able to achieve sufficient income to support a family with 2 children, according to the minimum wage standard of the City of Bandung. The informant went on to say that the efforts made will be rather difficult, related to the availability of capital, 
required land, and the provision of feed needed by bees. If the principle of vegetation requirements (for nectar, pollen and resin): bee colony (3:1) is applied, it will be very hard to make bee commercialization in this area.

Hitherto, farmer groups have not yet marketed their products commercially, definitely due to the scale of production is still very small. In general, the same obstacles are faced in the cultivation of stingless bees in Indonesia, such as the seasonal availability of products, limited amount of production, and limited marketing channel [9]. In relation to the availability of information, so far, the presence of group leaders is still very dominant in educating group members. The existence of agricultural and forestry extension workers is felt, but cannot replace the role of the leader of this community. This is in accordance with a study that show the role of leaders, one of which is to disseminate information, set an example, motivate, guide and mobilize the community [10], in this case it is related to the development of stingless bee farm on location.

\subsection{Motives and participation of community members}

According to Sukayat et al. [11] relation pattern among farmers and other actors can be categorized into five reasons which influences the motive of farmers conducting activities. These reasons are economic rationality (contract), friendship bonding (emotion), relatives/family support (genealogy), patron-client relation (power), and "support" from external/government through several development programs (power). In the "Tamalago" farmer group, since the beginning, the community kept bees mainly was for environmental protection reasons such as improving the physical environment in the area; not for financial/economic reasons, such as high stingless bee honey price, high demand into stingless bee honey; or for socio-policy reasons, such as following neighbours, influence from family or friends, or because of government programs.

If then social relations and cohesions improve, it will only be the impacts. Generally, all group members pointed out two main impacts of developing stingless bees in their area. First, the improvement in the condition of the physical environment around them, and second, the increase in social relations and cohesion among them.

Because it started with the intention to improve environmental conditions, the participation of group members in various group activities can be categorized to be good, both at the planning stage by providing ideas, suggestions, as well as in implementing and monitoring and evaluation stages of group activities. A number of contributions were also made by group members, both in the form of ideas, labour, providing skills, tools/goods, and money.

\subsection{Potential of stingless beekeeping activities for urban community development}

Community development has two definitions [12]. First, a process, in relation to developing and enhancing the ability to act collectively, and second, an outcome in terms of (a) taking collective action, and (b) the result of that action for improvement in a community in any realms such as physical, environmental, cultural, social, political, economic, etc.

Stingless bee farm in "Tamalago" farmer group contribute to several aspects in urban community development:

a. In relation to a process, stingless bee farm has been shown to increase the ability of communities to work together, enhance social relationships in order to achieve common goals. The life of urban communities, which tend to be individualistic [13], turns out to be more cohesive as a result of this stingless bee farm. 
b. In relation to the outcome, the existence of this cultivation activity encourages the community to act together, from the initial situation which was difficult to act together.

c. Although this bee farm has not yet reached a stage that is commercially profitable, the improvement in physical environmental conditions to become more convenient is an indirect impact of efforts to provide feed for bees. People realize that beekeeping is actually an effort to add vegetations around them, and we understand that basically vegetation play an important role in influencing urban air quality [14]

d. Stingless bee farm can also improve people's health status considering the nutritional content it has. Several researches show the numerous therapeutic profiles of this honey in terms of its antioxidant, antimicrobial, cytotoxicity, antiinflammatory $[15,16]$

e. Considering the various activities that urban communities have, the presence of stingless bees that can be kept without requiring a lot of time-consuming care has the potential to be an activity that can encourage social development of the community.

f. Although the price of the first colony is quite expensive, with the perseverance of community members and the support of other community members, cultivation of this stingless beekeeping is very possible.

g. Stingless bee farm encourages community members to properly maintain vegetation as bee feed, and indirectly improves the physical condition of the environment, as well as promotes better communication among community members.

h. If the stingless bee cultivation is increased in terms of economies of scale, and expanded by developing the tourism aspect, it will have the potential as a source of income and livelihood, at least for the community itself. It has been developed in several countries $[17,18]$. Even this location is more interesting because it is in an urban area.

i. Availability of many species of stingless bees that are harmless to people is potential to be cultivated, in an effort to increase public awareness of the importance of preserving the environment

\section{Conclusion}

Stingless bee farm has the potential to improve the processes and outcomes of urban community development, even though hitherto it has not been carried out commercially and profitable. Motives of the farm was for environmental protection reasons such as improving the physical environment in the area not for financial/economic reasons. The participation of group members in various group activities can be categorized to be good. Two major impacts received by the community are increased social cohesion among community members and improved quality of the physical environment in the area

\section{References}

1. J. Yu, J. Wu, Sustainability 10, 1776 (2018)

2. P. Manning, F. van der Plas, S. Soliveres. E. Allan, F. T. Maestre, G. Mace, M. J. Whittingham, M. Fischer, Nat. Eco. Evo. 2, 427-436 (2018)

3. F. Kalanzi, S. Nansereko, J. Buyinza, P. Kiwuso, Y. Turinayo, C. Myanja, G. Niyibiji, S. Ongerep, J. Sekatuba, D. Mujuni, Int. J. Res. Land Sustain. 2, 81-90 (2005) 
4. M. S. Engel, S. Kahono, D. Peggie, TREUBIA 45, 65-84 (2018)

5. E. Crane, The World History of Beekeeping and Honey Hunting (Routledge, New York, 1999)

6. C. Barbieri, T. M. Francoy, Sao Paulo 23, 1-20 (2020)

7. S. Kahono, P. Chantawannakul, M. S. Engel, Social Bees and the Current Status of Beekeeping in Indonesia (Springer, 2018)

8. A. Fitriyah, I. Mujiburrahman, Y. Mariani, J. Ag. Sci. 4, 2 (2020)

9. N. Winahyu, F. Amirudin, I. N. Azizah, J. Agribest 5, 1, 25-33 (2021)

10. E. S. Sulaeman, B. Murti, Waryana, J. Kesehat. Masy. Nas. 9, 4, 353-361 (2015)

11. D. Supyandi, P. Pardian, M. A. Heryanto, Organic Rice Development: How SocialEcological System Perspective Could Contribute, in Proceedings of the $6^{\text {th }}$ International Symposium for Sustainable Humanosphere, A Forum of Humanosphere Science School (HSS), 15-16 November 2016, Bogor, Indonesia (2017)

12. R. Phillips, R. H. Pittman (editor), An Introduction to Community Development, (Routledge, London, 2009)

13. Sumardjito, Cakrawala Pendidik. 18, 3, 131-135 (1999)

14. J. Badach, M. Dymnicka, A. Baranowski, Sustainability 12, 1258 (2020)

15. M. A. Abd Jalil, A. R. Kasmuri, H. Hadi, J. Skin. Phar. Phy. 30, 66-75 (2017)

16. M. Yaacob, N. F. Rajab, S. Shahar, R. Sharif, Food Res. 2, 2, 124-133 (2018)

17. R. H. Lemelin, J. Ecotourism 19, 1, 1-8 (2019)

18. P. Kunasekaran, N. Fuza, E.N.K.E. Hassan, S. Ramachandran, Int. J. Bus. Soc., 19, 6678 (2018) 